\title{
Psychological distress in postpartum: influence of late preterm delivery
}

\author{
Zanardo Vincenzo ${ }^{*}$, Francesca Volpe, Rita Maione, Arturo Giustardi, Gianluca Straface \\ From XX National Congress of the Italian Society of Neonatology \\ Rome, Italy. 9-11 October 2014
}

\begin{abstract}
Background
Psychological distress in women during the postpartum period has been for a while an issue of great concern. There is substantial evidence that maternal psychological distress after pregnancy is associated with an adverse cognitive and behavioural consequence in the offspring [1]. There are also severe implications during the perinatal period for the mother's long term mental health $[2,3]$, her partner's mental health $[4,5]$, and for the parental relationship [6]. The growing trend in late preterm deliveries suggests research on postpartum psychological distress risk in this group of vulnerable women.
\end{abstract}

\section{Materials and methods}

This prospective case control study was performed with the approval of the ethics committee, in accordance with the Declaration of Helsinki. Women who gave birth from $34 / 0$ to $36 / 6$ weeks and the next women who gave birth from $37^{\mathrm{g}}$ to $40 / 6$ weeks able to give informed consent were eligible.Three days after childbirth, mothers of late preterm infants $(n=42)$ and the next mother of at term infant, matched for parity and delivery route $(\mathrm{n}=42)$ completed medical history that covered key demographic and social information and the following questionnaires: State-Trait Anxiety Inventory questionnaire (STAI-Y) [7], Edinburgh Postnatal Depression Scale (EPDS) [8], and Psychological Stress Measure (PSM [9]).

\section{Results}

Findings show that mothers of late preterm infants, presenting with comparable key demographic and social antenatal risk factors, have more stress, anxiety, and depression than mothers of at term infants (State Anxietystate $42.6 \pm 5.3$ vs $49.5 \pm 9, \mathrm{p}<0.0002$; Anxiety-trait $39 \pm$ 6.1 vs $45.8 \pm 10.1, \mathrm{p}<0.02$; EPDS $6.3 \pm 3.9$ vs $9.5 \pm 4.5$,

\footnotetext{
* Correspondence: vincenzo.zanardo@libero.it

Policlinico Abano Terme, Piazza Colombo 1, 35031 Abano Terme, Italy $\mathrm{p}<0.008$; PSM $38.9 \pm 4.5$ vs $46 \pm 5.9, \mathrm{p}<0,001)$. In addition, Anxiety-state levels were associated with longer time to stay in hospital (days $6.1 \pm 1.8$ vs $4.7 \pm 1.2$ : $\mathrm{p}<0.01$ ).

\section{Conclusions}

These data indicate that late preterm delivered mothers are at increased psychological risk in a critical phase for establish a correct mother infant relationship. This can happen in two ways: first of all perhaps, by averting preterms' delivery and secondly by working through the distress. Moreover, what should be consider of great importance during the postpartum period is the presence of an entourage that can help relieve the mother from psychological distress and to support her and her child in case of acute symptoms [10]. Taking into account all these consideration it would be great to be able to arrange a psychological treatment for these mothers $n$ terms of their immediate and future well-being. and must therefore be targeted for intervention.

\section{Published: 9 October 2014}

\section{References}

1. Younger JB, Kendell MJ, Pickler RH: Mastery of stress in mothers of preterm Infants. I Spec Pediatr Nurs 2007, 2(1):29-35.

2. Hammen C: Risk and protective factors for children of depressed parents. In Resilience and vulnerability. New York: Cambridge University Press;S. Luthar 2003:34-41.

3. Philipps LHC, O'Hara MW: Prospective study of postpartum depression: 41/2-year follow-up of women and children. J Abnorm Psychol 1991, 100:151-155.

4. Harvey I, McGrath G: Psychiatric morbidity in spouses of women admitted to a mother and baby unit. Brit J Psychiat 1988, 152:506-510.

5. Lovestone S, Kumar R: Postnatal psychiatric illness: the impact on partners. Brit J Psychiat 1993, 163:210-216.

6. Boyce P: Personality dysfunction, marital problems and postnatal depression. In Perinatal psychiatry: use and misuse of the Edinburgh Postnatal Depression Scale. London, England: Gaskell;Cox J, Holden J 1994:82-102.

7. Spielberger CD, Gorsuch RL, Lushene RE: Manual for the State-Trait Anxiety Inventory. Palo Alto, CA: Consulting Psychologists Press; 1980. 
8. Cox JL, Holden JM, Sagovsky R: Detection of postnatal depression: Development of the 10-item Edinburgh Postnatal Depression Scale. B J Psychiat 1987, 150:782-786.

9. Lemyre L, Tessie R: Measuring psychological stress: Concept, model, and measurement instrument in primary care research. Can Fam Physician 2003, 49:1159-1560.

10. Raju TN, Higgins RD, Stark AR, Leveno KJ: Optimizing care and outcome for late-reterm(near-term) infants: a summary of the workshop sponsored by the national 188 institute of child health and human development. Pediatrics 2006, 118:1207-1214.

doi:10.1186/1824-7288-40-S2-A6

Cite this article as: Vincenzo et al:: Psychological distress in postpartum: influence of late preterm delivery. Italian Journal of Pediatrics 201440

(Suppl 2):A6.

\section{Submit your next manuscript to BioMed Central} and take full advantage of:

- Convenient online submission

- Thorough peer review

- No space constraints or color figure charges

- Immediate publication on acceptance

- Inclusion in PubMed, CAS, Scopus and Google Scholar

- Research which is freely available for redistribution

Submit your manuscript at www.biomedcentral.com/submit 